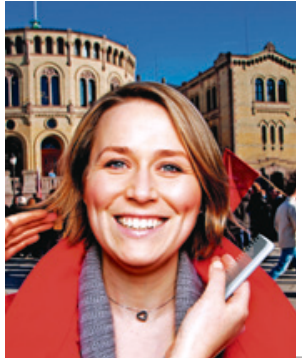

Olaug Nilssen

Forfatter

Foto Lars Myren Holand

\title{
Slik mistet hun ikke babykiloene
}

\author{
Oksehunger er ikkje ei orsaking \\ for overeting. I alle fall ikkje ei \\ god orsaking.
}

Eg har ei veninne, lat oss kalle henne Oddlaug, som slit med å kvitte seg med babykiloa etter å ha fødd sitt tredje barn for åtte månader sidan. I samtale med andre kan ho av og til tilgje seg sjølv for dette, ettersom det blir lite tid til å trene med tre små barn, og dette får ho også som regel støtte for, ofte saman med ein trøystande kommentar om at åtte månader er då ingenting! Korleis nokon får tid til å trene utover barnevogntrillinga, er ei gåte for absolutt alle, kan det verke som, og dessutan er det ingen som har tid til å vege mat og telje kaloriar i denne fasen. For ikkje å snakke om korleis behovet for mat aukar når ein søv lite, det er eit vitskapleg faktum, hevdar folk, og Oddlaug tar til seg denne informasjonen og gøymer den i hjartet sitt.

Andre gongar kan ho rase og gestikulere, ettersom gravidkleda er for store og alle dei gamle kleda er for små, slik at ho anten blir gåande rundt kledd som ein potetsekk eller har så trange kjolar at strømpebuksestrikken blir synleg midt på magen og ammeinnlegga tyt ut av den plutseleg enorme utringinga. Kvifor kjøper ikkje Oddlaug seg noko nytt? Ho vil ikkje kjøpe seg noko nytt! Ho vil gå ned to storleikar og deretter ta i bruk det ho hadde frå før! Dette er både miljøvenleg og økonomisk, argumenterer ho, og når ho likevel går i klesbutikken under januarsalet, fortel ho det same til ekspeditrisene: «Eg er på veg ned i vekt,» påstår ho, så eg må ha noko midlertidig. «Då gjer det ikkje noko at denne kjolen er litt trang,» seier ekspeditrisa tørt.
Oddlaug les alle «slik mistet hun babykiloene»-sakene på nettavisene. Ikkje fordi ho eit øyeblikk trur at ho skal få nokre gode tips, snarare for å snøfte irritert, uansett om dei slanke damene oppgir at amming er einaste grunn eller om dei innrømmer harde trenings- og kostholdsregimer. «Ein skal jo ikkje slanke seg når ein ammar,» seier Oddlaug, «det går ut over mjølkekvaliteten og dermed også ut over barnet.» Så et ho opp dei to brødskivene som blei til overs frå unganes frukost, slik at ho skal sleppe å kaste dei.

Under graviditeten var det jordmora som velviljug åtvara mot slanking då Oddlaug sat og okka og oia seg over kor fort vekta auka. Jordmora var ikkje uroa, ettersom Oddlaug løgnaktig oppgav at ho berre åt sunn mat, kanskje litt mykje, men ho hadde eit sunt og variert kosthold. «Og så blir det litt is i varmen, no då», la ho til, og fekk godkjenning for det. Så var det rett heim for å ete sjokolade så fort ho kunne, for å understreke overfor seg sjølv at dette var eit unnatak og ikkje ein regel. Neste dag var det søt gjærbakst, som så mange får eit kraftig sug etter i gravditeten, noko som kan tyde på at kroppen ikkje forstår at han faktisk veks utan ekstra hevingsmiddel.

Kvifor bryr Oddlaug seg om at kroppen forfell? Ho har fødd tre vakre og elskelege barn og burde takke kroppen sin for det, i staden for å irritere seg. Dessutan finst det mykje glede i feit og fløyterik mat, kvifor kan ho ikkje berre tenke på kaker og fløytegratinerte poteter som ein premie til kroppen etter alt han har gått gjennom i dei siste åras graviditetar?

Er det samfunnet og media som tvingar Oddlaug til å slanke seg, eller rettare tenke på å slanke seg? Nja, Oddlaug er nok mykje meir bekymra for presset tenåringar blir utsette for, det er trass alt uansett ingen som krev av henne at ho skal dusje naken saman med jamnaldringar eller ventar at ho skal legge ut bilete av seg sjølv i bikini på ein eller annan dertil eigna nettstad. Dessutan meiner ho heilt oppriktig at ho aldri i livet ville kledd ein knekkebrødtynn kropp, det er ikkje det ho strekk seg etter, ho vil berre sjå fin ut i dei gamle kjolane sine! (Og føle seg vel, ha meir overskot og energi til ungane osv.)

«Det er på tide å kalle ein spade for ein kakespade,» seier Oddlaug, for fjortande gong etter at babyen kom til verda. «Oksehunger er inga orsaking for overeting!» slår ho fast. «l alle fall ikkje ei god orsaking,» legg ho til og gir seg i kast med knekkebrøda og magerosten. Men etter ein halv dag kjenner ho korleis svolten gneg, etter trekvart dag kjenner ho korleis humøret synk og etter fullgått dag er ho så sur at verken mann eller barn synest ho er til å halde ut med. Dette er ikkje forsvarleg, tenkjer Oddlaug, endå ho veit det berre er ei kneik.

Lat meg vere eit føredøme for andre i same situasjon, tenkjer Oddlaug desperat $f \varnothing r$ ho tar bilete av ein stabel med vaflar og set seg godt til rette i sofaen med mac-en i fanget.

«Slik mistet hun ikke babykiloene,» skriv ho lakonisk på Facebook som bilettekst og gir seg til å vente på oppmuntrande «likes».

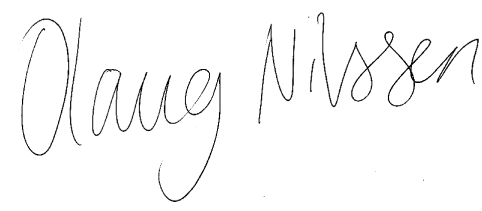

